\title{
Epidemiological and clinical characteristics of childhood pandemic 2009 H1N1 virus infection: an observational cohort study
}

\author{
Jung-Woo Rhim ${ }^{1,2}$, Kyung-Yil Lee ${ }^{1,2^{*}}$, You-Sook Youn ${ }^{1,2}$, Jin-Han Kang ${ }^{1}$ and Ji-Chang Kim³
}

\begin{abstract}
Background: There was a pandemic influenza around the world in 2009 including South Korea since last pandemic occurred four decades ago. We aimed to evaluate the epidemiological and clinical characteristics of this infection in childhood.

Methods: We evaluated the epidemiologic characteristics of all the subjects infected with the $2009 \mathrm{H} 1 \mathrm{~N} 1$ influenza A virus (2,971 patients, $\leq 15$ years of age), and the clinical and laboratory findings of the inpatients (217 patients, 80 had pneumonia) between 1 September 2009 and 31 January 2010 in a single hospital throughout the epidemic.

Results: The age distribution of all the subjects was relatively even. Over $90 \%$ of cases occurred during a twomonth period. Two hundred and five patients (94.5\%) received oseltamivir within $48 \mathrm{~h}$ of fever onset, and $97 \%$ of inpatients defervesced within $48 \mathrm{~h}$ of medication. The group with pneumonia included more males than females, and had higher leukocytes counts with lower lymphocyte differentials than the group without pneumonia. The white blood cell count and lymphocyte differential were associated with the severity of pneumonia. Corticosteroid treatment for severe pneumonia patients was highly effective in preventing disease progression.

Conclusion: Children of all ages affected with even rates of infection, but males were predominant in pneumonia patients. Pneumonia patients showed lymphopenia and its severity was associated with the severity of illness. Our results suggest that the mechanism of lung injury in $2009 \mathrm{H} 1 \mathrm{~N} 1$ virus infection may be associated with the host immune response.
\end{abstract}

\section{Background}

Although influenza virus infection has been a major global concern since the pandemic 1918 'Spanish flu', there have been no pandemic influenzas for near four decades after the 1968 'Hong Kong flu'. The pandemic 2009 H1N1 influenza A (2009 H1N1) virus infection was reported first in Mexico in February 2009, and then the virus spread rapidly worldwide, including in South Korea [1]. It has been reported that the majority of $\mathrm{H} 1 \mathrm{~N} 1$ patients were children and young adults and the mortality rate was not higher than that of seasonal influenza [2-4]. The majority of patients affected by the 2009 H1N1 virus infection recovered uneventfully, but some

\footnotetext{
* Correspondence: leekyungyil@catholic.ac.kr

'Departments of Pediatrics, College of Medicine, The Catholic University of Korea, 505 Banpo-dong, Seocho-gu, Seoul 137-701, Republic of Korea Full list of author information is available at the end of the article
}

previously healthy patients developed a rapidly progressive pneumonia, leading to acute respiratory distress syndrome (ARDS), multi-organ failure, and death [5-7]. With this enigma, the pathogenesis of acute lung injury (pneumonia) in influenza infections remains unknown $[1,8,9]$.

In South Korea, the first patient with 2009 H1N1 virus infection was reported in May, 2009. The number of patients gradually increased until mid-October, when the number of patients was overwhelming for a month, and then gradually decreased, with few people becoming infected after February, 2010. Owing to sensational reports of childhood fatality in the mass media and a new diagnostic tool, the real-time reverse transcriptase-polymerase chain reaction (RT-PCR), we had the opportunity to evaluate patients with $2009 \mathrm{H} 1 \mathrm{~N} 1$ virus infection from the onset of their illness. In addition, during the study period

\section{C) Biomed Central}


we observed a dramatic effect of early treatment with corticosteroids and oseltamivir for patients with severe pneumonia including rapidly progressive pneumonia $[9,10]$. In this study, we evaluated the epidemiological, clinical and laboratory features of children with 2009 H1N1 virus infections in a single hospital throughout the epidemic.

\section{Methods}

We retrospectively evaluated all patients with 2009 H1N1 virus infection during the pandemic (2,971 patients) for epidemiologic characteristics, and for clinical characteristics, we reviewed the medical records and chest radiographic findings of 217 children admitted to The Catholic University of Korea, Daejeon St Mary's Hospital between 1 September 2009 and 31 January 2010. The diagnosis of patients depended on positive results for the $2009 \mathrm{H} 1 \mathrm{~N} 1$ virus RT-PCR (AccuPower ${ }^{\mathrm{TM}}$ in Korea, BiONEER, Alameda, CA, USA) through throat swabs.

Although indications for admission were not clearly defined in this study, the majority of the inpatients were those who were suspected to have severe disease such as pneumonia and to have risk factors for severe disease such as infants and bronchial asthma. However, it might be possible that excessive concern of parents on fatality of this infection in part affected on admission of the uncomplicated cases. Among the 217 inpatients, we selected 80 patients with pneumonia and 137 patients without pneumonia, based on the chest radiographs. The chest radiographic patterns of admitted patients were reviewed and classified by two pediatricians (KY Lee and JW Rhim) and one pediatric radiologist (JC Kim). The patients with chest radiographic patterns that showed increased nodular densities along the bronchial trees unilaterally or bilaterally, were designated the bronchopneumonia group (49 patients). Patients with a distinctive large patch of infiltration, segmental or lobar consolidations were designated the segmental/lobar pneumonia group and regarded as having a severe pneumonia (31 patients). The first day of fever was regarded as the first day of illness. Among pneumonia patients, we tried corticosteroid treatment for 17 patients with severe pneumonia. As for indication of corticosteroids (methyprednisolone, MP or prednisolone), the subjects had severe respiratory distress with hypoxemia at presentation (12 cases) or during hospitalization (5 cases) requiring $\mathrm{O}_{2}$ therapy $(9,10)$. We compared the clinical and laboratory characteristics of the different groups.

The study was approved by the Institutional Review Board of the Catholic University of Korea, Daejeon St Mary's Hospital.

\section{Statistical analysis}

Statistical analyses were performed using the Statistical Package for the Social Sciences for Windows version
12.0 (SPSS, Chicago, IL, USA). Continuous variables are reported as means \pm standard deviations. Statistical significance was assessed using the Student's $t$-test and the paired $t$-test for continuous variables, and using the $\chi^{2}$ test for categorical variables. A $P$ value of $<0.05$ was considered significant for the statistical tests.

\section{Results}

Epidemiological features of the patients with 2009 H1N1 virus infection

During the study period, 5,975 children (aged 2 months15 years) with influenza-like illness were seen at our hospital. Among them, the 2,971 patients were positive by RT-PCR, and 217 patients were admitted to the isolation wards. The hospitalization rate was $7.3 \%$. The mean age of the patients $(2,971$ cases $)$ was $7.6 \pm 4.1$ years of age and the male-to-female ratio was 1.1:1 $(1,581 / 1,390)$. The age distribution of the patients is shown in Figure 1. Children of all age groups except infants had a relatively even rate of infection (Figure 1, gray bars). The numbers of new patients each week is shown in Figure 2. There was an explosive pattern, with over three quarters of the cases occurring during a single month (the 43rd-47th weeks of 2009; 18 October to 14 November). The age distribution and the weekly case rate of the patients admitted to hospital (217 cases) are also shown on Figure 1 and 2 (black bars). These demonstrated similar patterns to those of the total patient cohort. For hospitalization rates, younger children (0-4 years, 9.8\%, 75/762) showed higher admission rates than older children (5-9 years, 8.6\%, 104/1216 and 10-15 years, 3.8\%, 38/993).

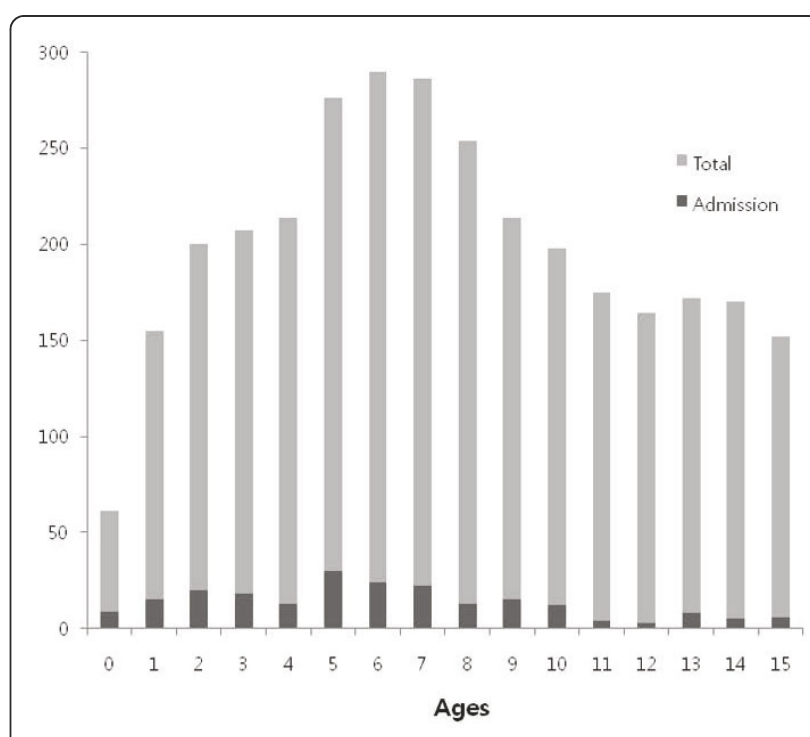

Figure 1 Age distribution of the H1N1 virus infected patients 


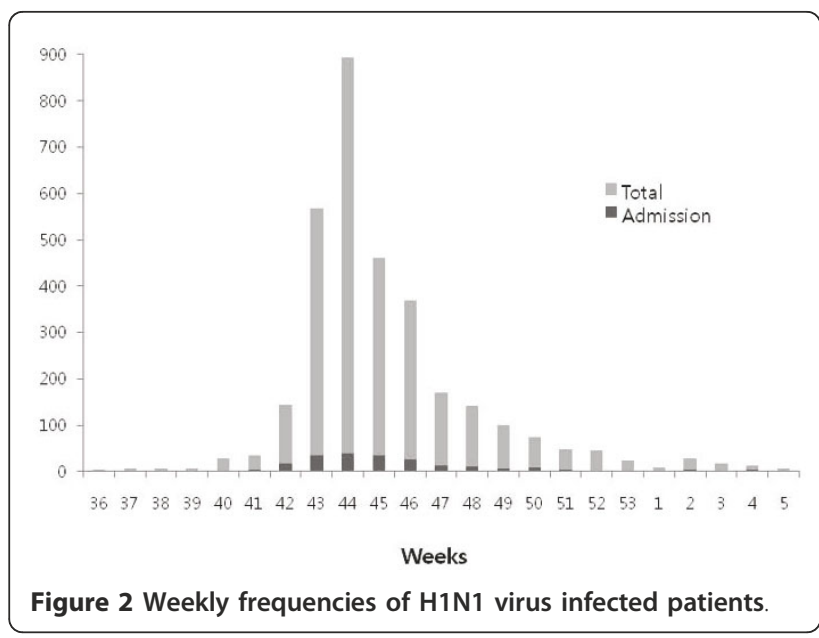

\section{Clinical features of the patients admitted with 2009 H1N1 virus infection}

In the 217 hospitalized children, the mean age was $6.2 \pm$ 3.7 years, and the male-to-female ratio was 1.6:1 (132/85). Almost all the patients had a high fever (97.2\%) and cough (92.6\%) suggestive of severe infection such as pneumonia at the time of admission. Most of the patients were previously healthy although some had underlying diseases and only 17 patients had underlying disorders (7.8\%), including 11 chronic pulmonary diseases (10 patients with bronchial asthma and one with past history of brochopulmonary dysplasia), 4 neuromuscular disorders (two with epilepsy and two with cerebral palsy), one with chronic liver disease, and one with nephrotic syndrome. The outcomes for these patients were uneventful, except for two asthmatic patients who developed a mild pneumonia. All inpatients received oseltamivir of the recommended doses for body weight and a broad-spectrum antibiotic (ampicillin/sulbactam). Two hundred and five patients (94.5\%) received oseltamivir within $48 \mathrm{~h}$ of fever onset. The mean duration of fever before admission (including the day of admission) was $2.0 \pm 0.8 \mathrm{~d}$ and 167 patients (77\%) defervesced on the next day. Only seven patients had fever that persisted $>48 \mathrm{~h}$ after oseltamivir treatment. During hospitalization, five patients showed progressive pneumonia despite early antiviral therapy.

According to the initial chest radiographs, 80 patients had pneumonia and were divided into two groups: the bronchopneumonia group (49 patients) and the segmental/lobar pneumonia group (31 patients). In pneumonia patients, pneumonic infiltrations appeared within $48 \mathrm{~h}$ of fever onset in 68 patients $(85 \%)$. When we analyzed the inpatients according to age (0-4 years, 75 patients; $5-9$ years, 104 patients; and 10-15 years, 38 patients), the rates of pneumonia in each age group were $36.0 \%(27 / 75)$, $45.2 \%(47 / 104)$ and $8.8 \%(6 / 38)$, respectively. The severe pneumonia (segmental/lobar type) was predominant in the older age groups (14.8\% (4/27), 48.9\% (23/47) and 50\% (3/6), respectively).

Among the 80 pneumonia patients, 17 patients showed severe respiratory distress with hypoxemia at presentation (12 cases) and during their hospital stay (5 cases). Arterial blood gas analysis was done in 15 patients, and 12 patients showed hypoxemia $\left(\mathrm{PO}_{2}<60 \mathrm{mmHg}\right.$ in the room air). These patients received additional corticosteroids as soon as possible when indicated; 12 patients received intravenous $\mathrm{MP}$ (10 $\mathrm{mg} / \mathrm{kg} /$ day, divided two doses, at presentation, $5 \mathrm{mg} / \mathrm{kg} /$ day at next day and then tapered off within a week) and 5 patients received oral prednisolone $(1 \mathrm{mg} / \mathrm{kg} /$ day, divided 3 doses, for 3 days tapered off within a week). Six patients received early MP with osetalmivir which is recommended early use, before the positive RT-PCR results. Interestingly, all patients except one (age 4 years) were among the 5-9 years age group, and male patients were predominant (13/17). We performed serial chest radiographs of some cases in these patients. A 6-year-old male patient complained of one day fever and cough, and his initial chest radiograph showed few pulmonary infiltrations. On the following morning, he complained of severe dyspnea and showed chest radiographic infiltrations on right lower lung and left hilar regions. He had received two doses of oseltamivir before the MP treatment (Figure 3A-C). A 7 year-old male patient was presented with a day fever and severe cough and had a rapidly progressive pneumonia in which initial patchy infiltrates on left upper lobe progressed to total left lung consolidation within $12 \mathrm{~h}$ after admission. He was given three doses of oseltamivir before the MP treatment (Figure 4A-G). These two patients showed dramatic improvements in their clinical symptoms and radiographic findings within $24 \mathrm{~h}$ after MP treatment. A 7-year-old male patient with lobar pneumonia was treated with oseltamivir, MP and intravenous immunoglobulin (IVIG) treatment. He was admitted with fever, cough and progressive dyspnea of 2 days, and after MP (10 mg/ $\mathrm{kg}$ /day, divided 2 doses) infusion, he showed persistent dyspnea and slightly aggravated pneumonic consolidation (Figure 5C). On the following morning, high-dose IVIG $(1 \mathrm{~g} / \mathrm{kg})$ was infused for 6 hours. At the time of termination of IVIG, his clinical symptoms disappeared and a dramatic improvement of radiographic findings was observed within 6 hours after IVIG termination (Figure $5 \mathrm{~A}-\mathrm{F})$. There was no adverse or rebound reaction in any patient treated with corticosteroids. The clinical symptoms of all patients improved within a day and their pneumonic infiltrations, regardless of severity, ceased immediately after corticosteroid treatment and disappeared within several days without adverse reactions.

Extrapulmonary manifestations (complications) of H1N1 infection were observed as four cases of febrile 


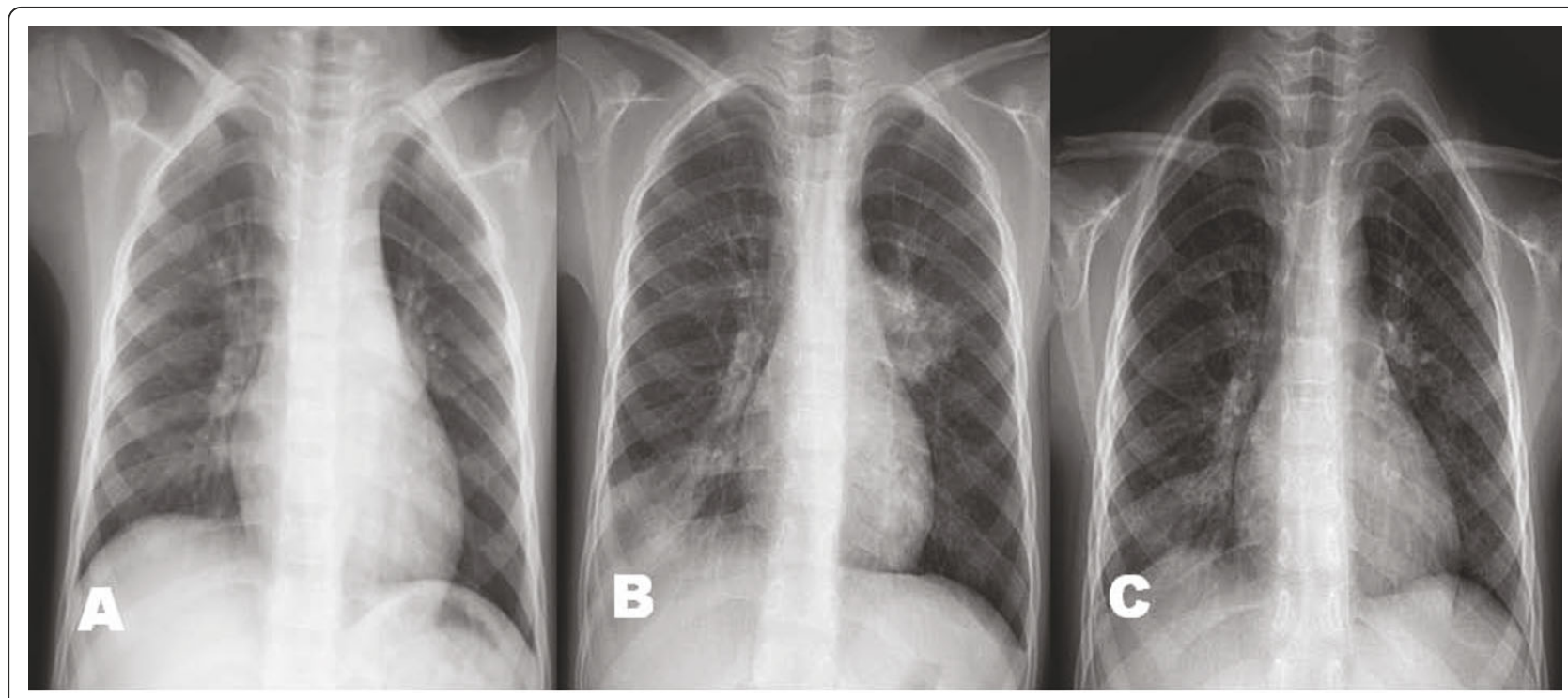

Figure 3 The chest radiographs of a patients who had progressive pneumonia during hospitalization (male, 6-year old); on admission (Figure 3-A), before methyprednisolone (MP) treatment (2nd hospital day, Figure 3-B), and 1 day after MP treatment (Figure 3-C).

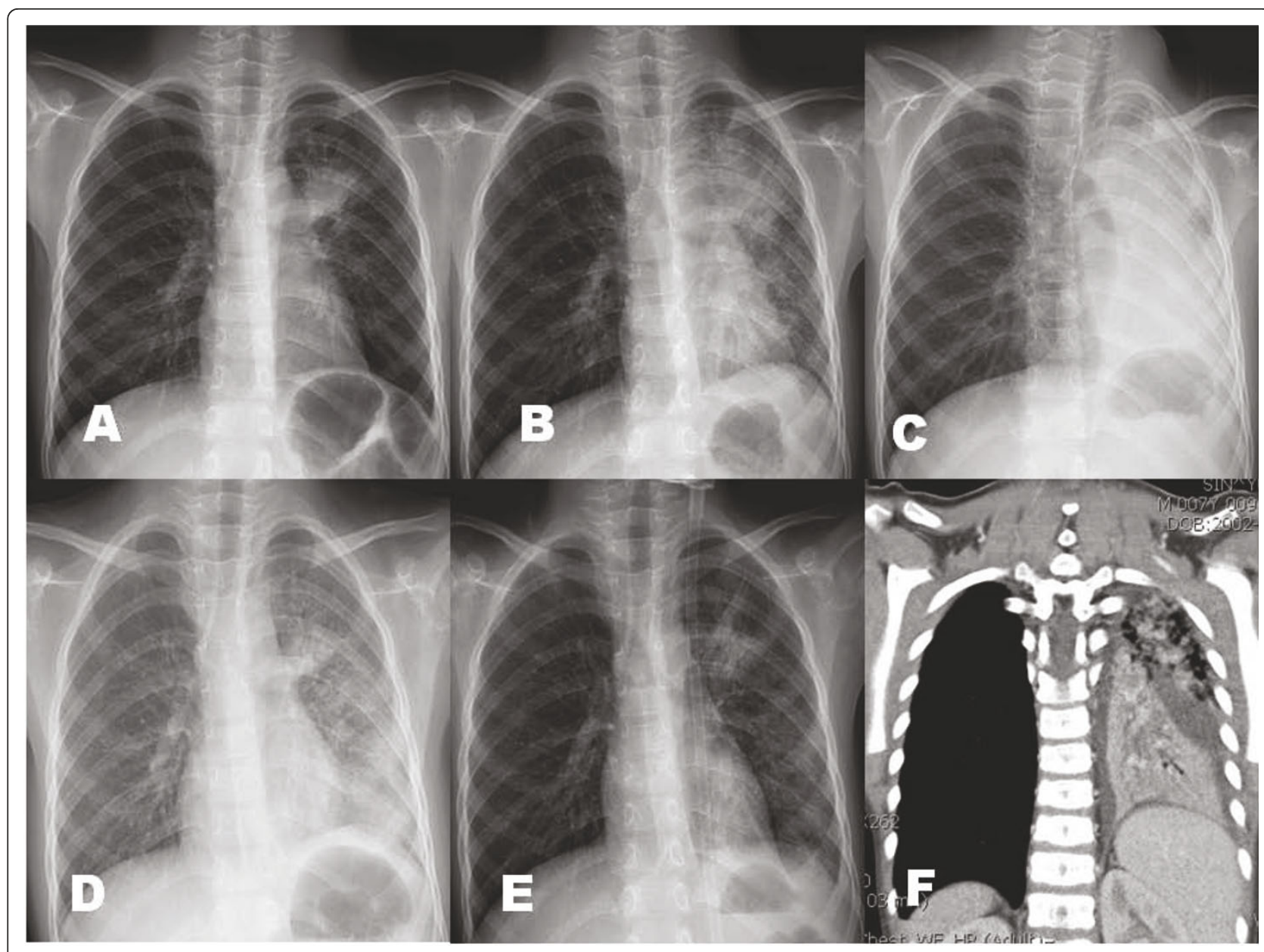

Figure 4 The chest radiographs of another patient who had rapidly progressive pneumonia during hospitalization (male, 7-year old); on admission (Figure 4-A), 2nd hospital day a.m. (Figure 4-B), 2nd hospital day p.m. (Figure 4-C), $3 \mathrm{~h}$ after MP treatment (Figure 4-D), $15 \mathrm{~h}$ after MP treatment (3rd hospital day, Figure 4-E), and a chest computed tomography finding on 2 nd hospital day p.m. (Figure 4-F). 


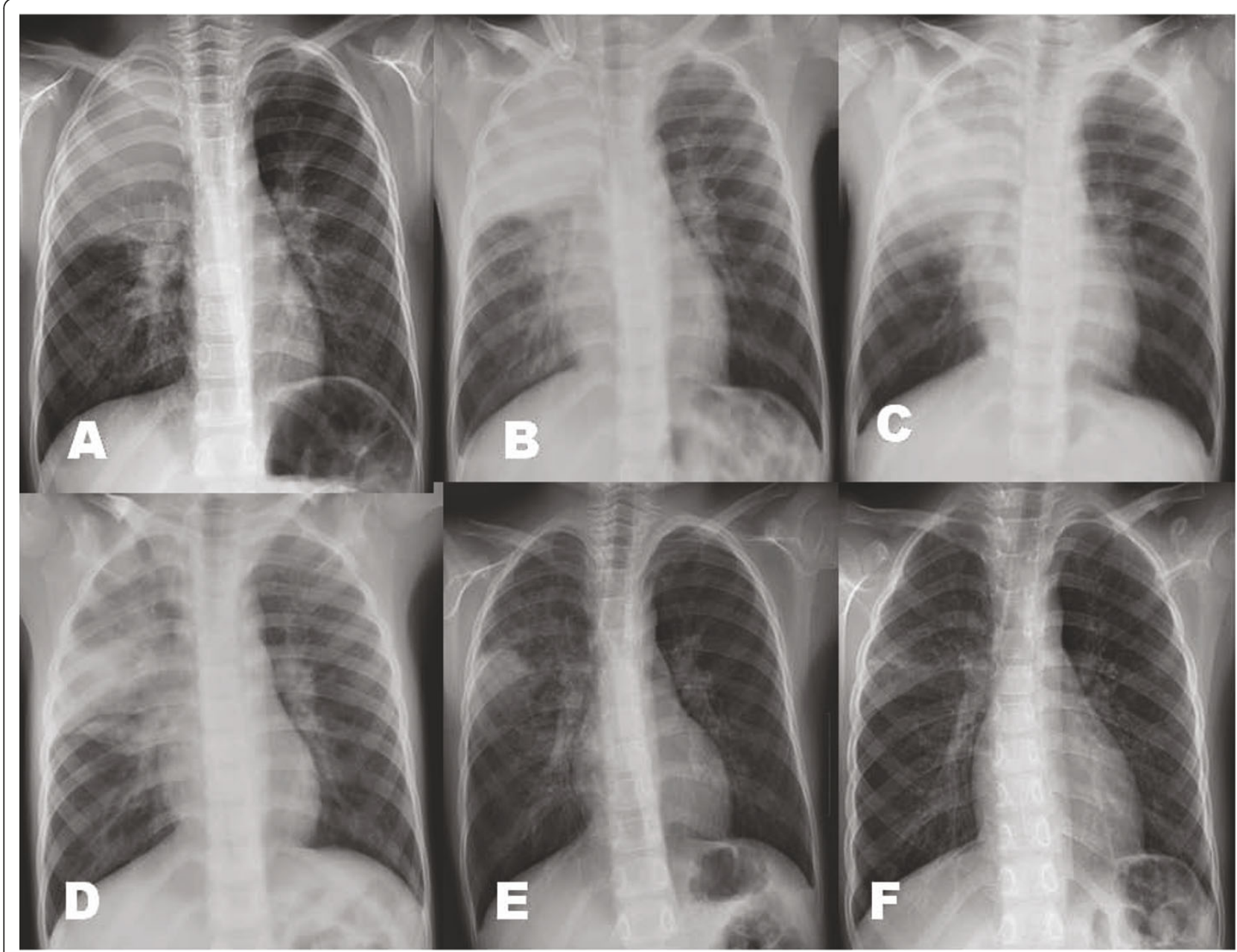

Figure 5 The chest radiographs of a patient who were treated with MP and intravenous immunoglobulin (IVIG) (male, 7-year old); on admission (Figure 5-A), before MP treatment (Figure 5-B), after 2 doses of MP infusion (Figure 5-C), just after termination of IVIG infusion (Figure 5-D), $8 \mathrm{~h}$ after IVIG infusion (Figure 5-E), and 3 days after MP and IVIG treatment (Figure 5-F).

seizure, two cases of urticaria, one case of hepatitis and one case of myositis, and no cases of encephalopathy.

\section{Laboratory findings of the inpatients with $2009 \mathrm{H} 1 \mathrm{~N} 1$ virus infection}

When we compared the patients with and without pneumonia, and the patients with segmental/lobar pneumonia versus those with bronchopneumonia, there were significant differences in certain parameters between the groups. Compared with the group without pneumonia, the males were over-represented in the pneumonia group $(P=0.001)$ and longer hospitalizations $(P<0.001)$, higher values for hemoglobin $(P=0.03)$, WBC $(P<0.001)$ and CRP $(P<0.001)$ and lower values for lymphocyte differential $(P<0.001)$ (Table 1$)$. The patients with the more severe type of pneumonia (segmental/lobar pneumonia) showed a higher mean age $(P=0.001)$ and leukocyte count $(P=0.01)$ and lower lymphocyte differential values
$(P<0.001)$ compared with the group with bronchopneumonia (Table 2). In addition, the severe pneumonia patients who received corticosteroids (17 cases) had the highest leukocyte counts and CRP levels, and the lowest lymphocyte differentials $\left(11800 \pm 3600 / \mathrm{mm}^{3}\right.$, $3.0 \pm 3.1 \mathrm{mg} / \mathrm{dL}$, and $8.8 \pm 6.3 \%$, respectively) [10].

\section{Discussion}

In this study, we found that children of all ages except infants had a relatively even rate of infection with the 2009 H1N1 influenza virus. This is in agreement with other studies showing that few children and young adults have immunity against a new viral infection $[2,11,12]$. Our study of all $2009 \mathrm{H} 1 \mathrm{~N} 1$ virus-infected children, in a single hospital, throughout the epidemic may have epidemiological implications, along with other studies based on data from admitted patients or gathered during a portion of the pandemic period [11-14]. It has been reported 
Table 1 Clinical and laboratory findings of patients infected with the 2009 H1N1 virus, with and without pneumonia

\begin{tabular}{|c|c|c|c|}
\hline Group & $\begin{array}{l}\text { No Pneumonia } \\
\quad(n=137)\end{array}$ & $\begin{array}{l}\text { Pneumonia } \\
(n=80)\end{array}$ & $P$ \\
\hline \multicolumn{4}{|l|}{ Clinical characteristics } \\
\hline Mean age $(y)$ & $6.5 \pm 4.0$ & $5.5 \pm 3.1$ & 0.04 \\
\hline Male/Female & $72 / 65$ & $60 / 20$ & 0.001 \\
\hline \multicolumn{4}{|l|}{ Duration of fever (d) } \\
\hline Before admission & $1.9 \pm 0.9$ & $2.0 \pm 0.9$ & NS \\
\hline Total & $2.2 \pm 1.0$ & $2.6 \pm 0.9$ & 0.006 \\
\hline Hospitalization (d) & $4.5 \pm 1.4$ & $5.6 \pm 1.3$ & $<0.001$ \\
\hline Oseltamivir, $<48 \mathrm{~h}(\mathrm{n}, \%)^{\mathrm{a}}$ & $130(95)$ & 75 (94) & NS \\
\hline \multicolumn{4}{|l|}{ Laboratory findings } \\
\hline Haemoglobin (g/dL) & $12.5 \pm 0.9$ & $12.8 \pm 1.0$ & 0.03 \\
\hline Leukocyte $\left(\times 10^{9} / \mathrm{L}\right)$ & $6.5 \pm 3.3$ & $8.8 \pm 3.7$ & $<0.001$ \\
\hline Neutrophil (\%) & $59 \pm 19$ & $69 \pm 20$ & $<0.001$ \\
\hline Lymphocyte (\%) & $30 \pm 17$ & $21 \pm 17$ & $<0.001$ \\
\hline Monocyte (\%) & $10 \pm 4$ & $8 \pm 4$ & 0.005 \\
\hline Platelet $\left(\times 10^{9} / \mathrm{L}\right)$ & $224 \pm 58$ & $241 \pm 61$ & 0.04 \\
\hline CRP $(\mathrm{mg} / \mathrm{dL})$ & $1.2 \pm 1.5$ & $2.4 \pm 2.5$ & $<0.001$ \\
\hline $\operatorname{ESR}(\mathrm{mm} / \mathrm{h})$ & $16 \pm 12$ & $18 \pm 13$ & NS \\
\hline
\end{tabular}

CRP; C-reactive protein, ESR; erythrocyte sedimentation rate. NS, statistically non-specific

${ }^{a}$ Number (\%) of patients who received oseltamivir treatment within $48 \mathrm{~h}$ of fever onset.

that younger children $(<4-5$ years old) with $\mathrm{H} 1 \mathrm{~N} 1$ virus infection tended to be admitted to hospital more frequently than older children or adults, and our results are compatible with these studies $[2,3,6]$. It has also been

Table 2 Clinical and laboratory findings according to the severity of pulmonary lesions

\begin{tabular}{|c|c|c|c|}
\hline Group & $\begin{array}{l}\text { Bronchopneumonia } \\
\qquad(\mathrm{n}=49)\end{array}$ & $\begin{array}{c}\text { Segmental/ } \\
\text { Lobar } \\
(\mathrm{n}=\mathbf{3 1})\end{array}$ & $P$ \\
\hline \multicolumn{4}{|l|}{ Clinical characteristics } \\
\hline Mean age (y) & $4.7 \pm 2.9$ & $6.9 \pm 2.9$ & 0.001 \\
\hline Male/Female & $37 / 12$ & $23 / 8$ & NS \\
\hline $\begin{array}{l}\text { Duration of fever } \\
\text { (d) }\end{array}$ & $2.6 \pm 1.0$ & $2.5 \pm 1.0$ & NS \\
\hline Hospitalization (d) & $5.2 \pm 1.2$ & $6.2 \pm 1.3$ & 0.001 \\
\hline $\begin{array}{l}\text { Oseltamivir, < } 48 \text { h } \\
(\mathrm{n}, \%)\end{array}$ & $46(94)$ & $29(94)$ & NS \\
\hline \multicolumn{4}{|l|}{ Laboratory findings } \\
\hline Haemoglobin (g/dL) & $12.6 \pm 1.0$ & $13.2 \pm 0.8$ & 0.006 \\
\hline Leukocyte $\left(\times 10^{9} / \mathrm{L}\right)$ & $8.2 \pm 3.5$ & $9.7 \pm 3.8$ & 0.01 \\
\hline Neutrophil (\%) & $64 \pm 21$ & $77 \pm 13$ & 0.001 \\
\hline Lymphocyte (\%) & $26 \pm 18$ & $14 \pm 11$ & $\begin{array}{c}< \\
0.001\end{array}$ \\
\hline Monocyte (\%) & $8 \pm 3$ & $7 \pm 4$ & NS \\
\hline Platelet $\left(\times 10^{9} / \mathrm{L}\right)$ & $231 \pm 58$ & $255 \pm 64$ & NS \\
\hline CRP (mg/dL) & $2.0 \pm 2.1$ & $3.0 \pm 2.8$ & NS \\
\hline ESR $(\mathrm{mm} / \mathrm{h})$ & $18 \pm 13$ & $16 \pm 13$ & NS \\
\hline
\end{tabular}

reported that certain risk factors are related to the likelihood of developing severe illness, including a younger age and particular underlying diseases, including obesity $[6,7,15,16]$. In this study, we did not analyze obesity and young age as risk factors, and only 17 patients (7.8\%) had underlying diseases. Although the hospitalization rate was higher among the younger children (0-4 years of age), in this study, pneumonia and severe pneumonia were more prevalent in the 5-9-year-old group than in younger children.

The explosive increase in the infection rate during two months (mid-October to mid-December) of the study period may be a typical pattern of spread of an acute respiratory viral infectious disease that has a short incubation period (1-3 days). This pattern is similar to those reported in other regions of Korea and other countries [3,4,17]. Vaccination against the $2009 \mathrm{H} 1 \mathrm{~N} 1$ influenza virus in Korea started on 18 November, 2009 for school-aged children, on 7 December, 2009 for children aged 6 months to 5 years and on 21 December, 2009 for adults with risk factors, which was after the peak of the epidemic. The rapid disappearance of the spread of infection might be the effect of vaccination and the strengthened individual hygiene, but the epidemiologic pattern suggests that an unknown herd immunity against a new viral infection might also be responsible $[3,17]$.

It is reported that patients with $2009 \mathrm{H} 1 \mathrm{~N} 1$ virus infections had a relative leukopenia with lymphopenia $[18,19]$. However addition to this finding, we found in the present study that the patients with pneumonia had a higher WBC count with lower lymphocyte differential, and the more severely affected patients had the highest WBC with the lowest lymphocyte differential in the early stages of the infection (within two days of fever onset). Previous human studies of $\mathrm{H} 5 \mathrm{~N} 1$ virus infections have revealed that a lower lymphocyte count was associated with a poor outcome [20], and mice infected with influenza viruses showed a lymphopenia and the H5N1 subtype was associated with marked lymphopenia with total lymphoid depletion [21]. Therefore peripheral lymphocyte may be associated with the pathogenesis of acute lung injury in influenza virus infections [9]. Altered CRP and ESR values were not prominent in $2009 \mathrm{H} 1 \mathrm{~N} 1$ virus infections, but higher CRP values were associated with a more severe illness.

The male-to-female ratio was 1.1:1 among all patients, and 1.6:1 among the admitted patients. Furthermore, male patients were predominant among those with pneumonia $(3: 1,60 / 80)$ and those with respiratory distress who received corticosteroids $(3.3: 1,13 / 17)$. Other epidemiologic studies on children have reported a male predominance [16], but some studies on inpatients have reported a female predominance $[4,7]$. These findings suggest that genetic factors and possibly environmental factors are 
associated with the pathogenesis of $2009 \mathrm{H} 1 \mathrm{~N} 1$ virus-associated pneumonia.

Regarding the pathogenesis of lung injury in influenza virus infections, it has been believed that the viruses from upper respiratory tract spread to lower lung tissues and elicit the cytopathic reaction. However, some clinical and experimental studies have suggested that the innate and/ or cell-mediated immune reaction ( $\mathrm{T}$ cell) with excessive production of cytokines of the host may also be responsible for the lung injury in influenza virus infection [9,22-25]. We experienced no intensive care patient in this series despite large subjects of the study, and it may be, at least in part, explained by a rapid use of corticosteroids on the patients with severe pneumonia $[9,10]$. Because this pandemic occurred over 40 years after last pandemic (Hong Kong flu), there have been no controlled-clinical trials for the efficacy of corticosteroids on influenza virus infections, although yearly seasonal influenza and small cases of sporadic H5N1 avian influenza virus infection have occurred during inter-pandemic period. The beneficial effect of corticosteroids in pneumonia caused by influenza virus infections may have resulted from reduction of systemic inflammation caused by immune cells and cytokines [26,27]. Our treatment policy which needs to be proven by controlled clinical studies in coming pandemics or in other influenza virus infections, may help to reduce the morbidity and possibly prevent the progression to fatal pneumonia $[9,10]$. We have reviewed the rationale of our corticosteroid treatment and the host immune responses to viral insults in influenza virus infections, and proposed a new concept for the pathogenesis of acute lung injury in influenza virus infections, using a 'protein homeostasis system' of the host [9].

It has been reported that antiviral therapy (oseltamivir) is effective in the acute stages of influenza infection, including $\mathrm{H} 1 \mathrm{~N} 1$ virus infection in humans and experimental animals $[4,28]$. In agreement with this, we found that the majority of patients (97\%) defervesced within 48 $\mathrm{h}$ after medication and most pneumonic infiltrations in pneumonia patients had improved at discharge.

There are some limitations to this study. Compared with other studies, we had many uncomplicated inpatients owing to flexibility of our admission policy. Because we did not perform extensive microbiological testing, such as viral cultures, paired-sample serologic studies and PCR for other pathogens, we cannot rule out the possibility of coinfection with other respiratory pathogens.

\section{Conclusions}

In pandemic $2009 \mathrm{H} 1 \mathrm{~N} 1$ virus infections, children of all ages were evenly affected, and males were predominant in pneumonia patients. Early antiviral treatment was very effective in inducing rapid defervescence for the patients.
The patients with 2009 H1N1 infections showed lymphopenia, and its severity was associated with the severity of the illness in the early stages. Together this finding, the rapid improvement in clinical signs and the prompt resolution of severe pneumonic consolidations after immunemodulator (corticosteroid and IVIG) treatment suggest that the mechanisms of lung injury in this infection may be associated with the cell-mediated immune response of the host, rather than virus-induced cytopathies.

\section{Acknowledgements}

There was no funding for this study. We thank Drs. Sung-Ku Kim, KyungWon Bang, Hyun-Oh Kim, Ji-Jung Lee and Ja-Young Hwang for patient care during the pandemic, and Drs. Jae-Wook Lee and Joon-Sung Lee for careful review of this paper.

\section{Author details}

'Departments of Pediatrics, College of Medicine, The Catholic University of Korea, 505 Banpo-dong, Seocho-gu, Seoul 137-701, Republic of Korea. ${ }^{2}$ Department of Pediatrics, The Catholic University of Korea, Daejeon St. Mary's Hospital, 520 Daeheung-dong, Jung-gu, Daejeon 301-723, Republic of Korea. ${ }^{3}$ Department of Radiology, The Catholic University of Korea, Daejeon St. Mary's Hospital, 520 Daeheung-dong, Jung-gu, Daejeon 301-723, Republic of Korea.

\section{Authors' contributions}

All authors read and approved the final manuscript. KYL had primary responsibility for concept, design of the study and writing the manuscript; JWR participated in the preliminary data collection, data analysis and writing the manuscript; YSY participated in patient care and data analysis; JHK contributed to the interpretation of the data and editing of the manuscript and supervised the design and execution of the study; JCK participated in reading of chest radiograph of the patients

\section{Completing interests}

The authors declare that they have no competing interests.

Received: 3 May 2011 Accepted: 24 August 2011

Published: 24 August 2011

\section{References}

1. Neumann G, Noda T, Kawaoka Y: Emergence and pandemic potential of swine-origin H1N1 influenza virus. Nature 2009, 459:931-939.

2. Centers for Disease Control and Prevention: Update: influenza activity United States, August 30, 2009-March 27, 2010, and composition of the 2010-11 influenza vaccine. Morb Mortal Wkly Rep 2010, 59:423-430.

3. Bishop JF, Mumane MP, Owen R: Australia's winter with the 2009 pandemic influenza A (H1N1) virus. N Engl J Med 2010, 361:2591-1594.

4. Torres JP, O'Ryan M, Herve B, Espinoza R, Acuna G, Manalich J, Chomali M: Impact of the novel influenza A (H1N1) during the 2009 autumn-winter season in a large hospital setting in Santiago, Chile. Clin Infect Dis 2010, 50:860-868.

5. Wriging commitee of the $\mathrm{WHO}$ consultaton on clinical aspect of pandemic (H1N1) 2009 influenza: Clinical aspects of pandemic 2009 influenza A (H1N1) virus infection. N Engl J Med 2010, 362:1708-1719.

6. The ANZIC Influenza Investigators: Critical care services and 2009 H1N1 influenza in Australia and Newzaeland. New Engl J Med 2009, 361:1925-1934.

7. Kumar A, Zarychanski R, Pinto R, Cook DJ, Marshall J, Lacroix J, Stelfox T, Bagshaw S, Choong K, Lamontagne F, Turgeon AF, Lapinsky S, Ahern SP, Smith O, Siddiqui F, Jouvet P, Khwaja K, Mclntyre L, Menon K, Hutchison J, Hornstein D, Joffe A, Lauzier F, Singh J, Karachi T, Wiebe K, Olafson K, Ramsey C, Sharma S, Dodek P, Canadian Critical Care Trials Group H1N1 Collaborative, et al: Critically ill patients with 2009 influenza A (H1N1) Infection in Canada. JAMA 2009, 302:1872-1879.

8. Eichelberger MC: The cotton rat as a model to study influenza pathogenesis and immunity. Viral Immunol 2007, 20:243-249. 
9. Lee KY, Rhim JW, Kang JH: Hyperactive immune cells (T cells) may be Responsible for acute lung injury in influenza virus infections: a need for early Immune-modulators for severe cases. Med Hypotheses 2011, 76:64-69.

10. Kil HR, Lee JH, Lee KY, Rhim JW, Youn YS, Kang JH: Early corticoid treatment for severe pneumonia caused by 2009 H1N1 influenza virus. Crit Care 2011, 22:413.

11. Novel Swine-Origin Influenza a (H1N1) Virus Investigation Team: Emergence of a novel swine-origin influenza $\mathrm{A}(\mathrm{H} 1 \mathrm{~N} 1)$ virus in humans. N Engl J Med 2009, 360:2605-2615.

12. Miller $E$, Hoschler $K$, Hardelid $P$, Stanford $E$, Andrews $N$, Zambon M: Incidence of 2009 pandemic influenza A H1N1 infection in England: a cross-sectional serologic study. Lancet 2010, 375:1100-1118.

13. Jain S, Kamimoto L, Bramley AM, Schmitz AM, Benoit SR, Louie J, Sugerman DE, Druckenmiller JK, Ritger KA, Chugh R, Deutscher M, Chen S, Walker JD, Duchin JS, Lett S, Soliva S, Wells EV, Swerdlow D, Uyeki TM, Fiore $A E$, Olsen SJ, Fry AM, Bridges CB, Finelli L, Pandemic Influenza A (H1N1) Virus Hospitalizations Investigation Team: Hospitalized patients with 2009 H1N1 influenza in the United States, April-June 2009. N Engl J Med 2009, 361:1935-1944.

14. Bettinger JA, Sauvé LJ, Scheifele DW, Moore D, Vaudry W, Tran D, Halperin SA, Pelletier L: Pandemic influenza in Canadian children: a summary of hospitalized pediatric cases. Vaccine 2010, 28:3180-3184

15. Louie JK, Acosta M, Winter K, Jean C, Gavali S, Schechter R, Vugia D, Harriman K, Matyas B, Glaser CA, Samuel MC, Rosenberg J, Talarico J, Hatch D, California Pandemic (H1N1) Working Group: Factors associated with death or hospitalization due to pandemic 2009 influenza $A(H 1 N 1)$ infection in California. JAMA 2009, 302:1896-1902.

16. O'Riodan S, Barton M, Yau Y, Reed SE, Allen U, Tran D: Risk factors and outcoms among children admitted to hospital with pandemic H1N1 influenza. CMJA 2009, 182:39-44.

17. Wichmann $O$, Stöcker $P$, Poggensee $G$, Altmann D, Walter D, Hellenbrand W, Krause G, Eckmanns T: Pandemic influenza A (H1N1) 2009 breakthrough infections and estimates of vaccine effectiveness in Germany 2009-2010. Euro Surveill 2010, 15(18), pii:19561.

18. Coşkun O, Sener K, Yaman H, Bodur H, Eyigün CP: Relative lymphopenia and monocytosis may be considered as a surrogate marker of pandemic influenza A (H1N1). J Clin Viol 2010, 47:388-389.

19. Saha A, Jha N, Dubey NH, Gupta VK, Kalaivani M: Swine-origin influenza A (H1N1) in Indian children. Ann Trop Pediatr 2010, 30:51-5.

20. Hien ND, Ha NH, Van NT, Ha NTM, Lien TTM, Thai NQ, Trang VD, Shimbo T, Takahashi Y, Kato Y, Kawana A, Akita S, Kudo K: Human infection with highly pathogenic avian influenza virus (H5N1) in Northern Vietnam, 2004-2005. Emerg Infect Dis 2009, 15:19-23.

21. Tumpey TM, Lu X, Morken T, Zaki SR, Katz JM: Depletion of lymphocytes and diminished cytokine production in mice infected with a highly virulent influenza A (H5N1) virus isolated from humans. J Virol 2000, 74:6105-6116.

22. De Jong MD, Simmons CP, Thanh TT, Hien VM, Smith GJ, Chau TN, Hoang DM, Chan NV, Khanh TH, Dong VC, Qui PT, Cam BV, Ha do Q, Guan Y, Peiris JS, Chinh NT, Hien T, Farrar J: Fatal outcome of human influenza $\mathrm{A}(\mathrm{H} 5 \mathrm{~N} 1)$ is associated with high viral load and hypercytokinemia. Nat Med 2006, 12:1203-1207.

23. Suzuki F, Ghya J, Ishida N: Effect of antilymphocyte serum on influenza virus infection in mice (38047). Proc Soc Exp Biol Med 1974, 146:78-84.

24. Wyde PR, Couch RB, Mackler BF, Cate TR, Levy BM: Effect of low- and highpassage influenza virus infection in normal and nude mice. Infect and Immun 1977, 15:221-229.

25. To KK, Hung IF, Li IW, Lee KL, Koo CK, Yan WW, Liu R, Ho KY, Chu KH, Watt CL, Luk WK, Lai KY, Chow FL, Mok T, Buckley T, Chan JF, Wong SS, Zheng B, Chen H, Lau CC, Tse H, Cheng VC, Chan KH, Yuen KY: Delayed clearance of viral load and marked cytoline activation in severe cases of pandemic H1N1 2009 influenza virus infection. Clin Infect Dis 2010, 50:850-859.

26. Confalonieri $M$, Urbino $R$, Potena A, Piattella $M$, Parigi $P$, Puccio $G$, Porta RD, Giorgio C, Blasi F, Umberger R, Meduri GU: Hydrocortisone infusion for severe community-acquired pneumonia. A preliminary randomized study. Am J Respi Crit Care Med 2005, 171:242-248.

27. Annane D: Pro: The illegitimate crusade against corticosteroids for severe H1N1 pneumonia. Am J Respir Crit Care Med 2011, 183:1125-1126.
28. Falagas ME, Vouloumanou EK, Baskouta E, Rafailidis PI, Polyzos K, Rello J: Treatment options for $2009 \mathrm{H} 1 \mathrm{~N} 1$ influenza: evaluation of the published evidence. Intern J Antimicrob Agents 2010, 35:421-430.

\section{Pre-publication history}

The pre-publication history for this paper can be accessed here: http://www.biomedcentral.com/1471-2334/11/225/prepub

\section{doi:10.1186/1471-2334-11-225}

Cite this article as: Rhim et al:: Epidemiological and clinical characteristics of childhood pandemic 2009 H1N1 virus infection: an observational cohort study. BMC Infectious Diseases 2011 11:225.

\section{Submit your next manuscript to BioMed Central and take full advantage of:}

- Convenient online submission

- Thorough peer review

- No space constraints or color figure charges

- Immediate publication on acceptance

- Inclusion in PubMed, CAS, Scopus and Google Scholar

- Research which is freely available for redistribution 